\title{
Chemical composition and in vitro digestibility of corn stover during field exposure and the fermentation characteristics of silage prepared with microbial additives
}

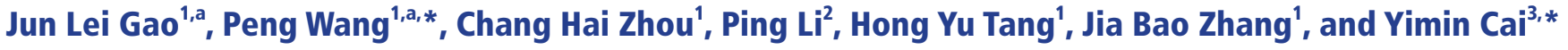

\author{
* Corresponding Authors: \\ Peng Wang \\ Tel: +86-431-87836170, Fax: +86-431-87836170 \\ E-mail: pengwang@jlu.edu.cn \\ Yimin Cai \\ Tel: +81-29-838-6365, Fax: +81-29-838-6316, \\ E-mail: cai@affrc.go.jp \\ ${ }^{1}$ College of Animal Science, Jilin University, Changchun \\ 130062, China \\ ${ }^{2}$ School of Architecture and Civil Engineering, \\ Changchun Sci-Tech University, Changchun 130600, \\ China \\ ${ }^{3}$ Japan International Research Center for Agricultural \\ Sciences, Tsukuba 305-8686, Japan \\ a These authors contributed equally to this article. \\ ORCID \\ Jun Lei Gao \\ https://orcid.org/0000-0003-4496-2693 \\ Peng Wang \\ https://orcid.org/0000-0001-6222-9546 \\ Chang Hai Zhou \\ https://orcid.org/0000-0003-4750-2107 \\ Ping Li \\ https://orcid.org/0000-0001-5985-2783 \\ Hong Yu Tang \\ https://orcid.org/0000-0002-6797-0058 \\ Jia Bao Zhang \\ https://orcid.org/0000-0001-8533-4744 \\ Yimin Cai \\ https://orcid.org/0000-0003-2650-5210
}

Submitted Nov 23, 2018; Revised Dec 22, 2018;

Accepted Mar 18, 2019
Objective: To effectively use corn stover resources as animal feed, we explored the chemical composition and in vitro digestibility of corn stover during field exposure and the fermentation characteristics of silage prepared with lactic acid bacteria (LAB) and cellulase.

Methods: Corn ears including the cobs and shucks were harvested at the ripe stage. The corn stover was exposed in the field under natural weather conditions. Silages were prepared after $0,2,4,7,15,30$, and $60 \mathrm{~d}$ of exposure. Corn stover was chopped into approximately 1 to $2 \mathrm{~cm}$ lengths and then packed into 5 liter plastic silos. The ensiling density was $550.1 \pm 20.0 \mathrm{~g} / \mathrm{L}$ of fresh matter, and the silos were kept at room temperature $\left(10^{\circ} \mathrm{C}\right.$ to $\left.25^{\circ} \mathrm{C}\right)$. Silage treatments were designed as follows: without additives (control), with LAB, with cellulase, and with LAB+ cellulase. After $45 \mathrm{~d}$ of fermentation, the silos were opened for chemical composition, fermentation quality and in vitro digestion analyses.

Results: After harvest, corn stover contained 78.19\% moisture, 9.01\% crude protein (CP) and $64.54 \%$ neutral detergent fiber (NDF) on a dry matter (DM) basis. During field exposure, the DM, NDF, and acid detergent fiber (ADF) contents of corn stover increased, whereas the $\mathrm{CP}$ and water-soluble carbohydrate contents and in vitro digestibility of the $\mathrm{DM}$ and $\mathrm{CP}$ decreased $(\mathrm{p}<0.05)$. Compared to the control silage, cellulase-treated silage had lower $(\mathrm{p}<0.05)$ $\mathrm{NDF}$ and $\mathrm{ADF}$ contents. The $\mathrm{pH}$ values were lower in silage treated with $\mathrm{LAB}$, cellulase, or $\mathrm{LAB}+\mathrm{cellulase}$, and lactic acid contents were higher $(\mathrm{p}<0.05)$ than those of the control. Silage treated with cellulase or $\mathrm{LAB}+$ cellulase improved $(\mathrm{p}<0.05)$ the in vitro $\mathrm{DM}$ digestibility (IVDMD) compared to that of the control or LAB-treated silage.

Conclusion: Corn stover silage should be prepared using fresh materials since stover nutrients are lost during field exposure, and $\mathrm{LAB}$ and cellulase can improve silage fermentation and IVDMD.

Keywords: Cellulase; Corn Stover; In vitro Digestibility; Lactic Acid Bacteria; Silage Fermentation

\section{INTRODUCTION}

Crop byproducts from agriculture are an important animal feed resource worldwide. In China, approximately 900 million tons of crop straw are produced annually, of which $30 \%$ is corn stover. After harvest, corn stover generally remains fresh and contains nutrients suitable for animal feed. Currently, at least 30\% of corn stover is used for animal production or papermaking, whereas the remainder is usually incinerated in the field or plowed back into the soil after pulverization [1]. In recent years, the continuous degeneration of native grasslands has created a structural shortage of feed resources for herbivorous animal husbandry. Therefore, the effective use of corn stover resources to preserve fermented feed has become an urgent research topic globally, particularly in China. 
Ensilage is an effective method for processing and utilizing forage. Corn stover silage is currently widely used as ruminant feed in animal husbandry. However, following corn grain harvest, when exposure time is prolonged, corn stover moisture and nutrients decrease and lignification increases, resulting in decreased digestibility for animals [2]. Therefore, selecting the proper time for ensilage following corn harvest is an important condition for obtaining high-quality corn stover silage.

Microbial additives such as lactic acid bacteria (LAB) and cellulase are widely used in silage preparation [3]. LAB plays an important role in aiding fermentation and preventing spoilage. Cellulase acts as a biocatalytic agent in the decomposition of cellulose; as a water-soluble carbohydrate (WSC), the cellulose decomposition product can be used by LAB to promote fermentation [4]. Many studies have demonstrated that using LAB or cellulase additives improves fermentation quality and nutritive value [5].

Despite previous studies focusing on forage, grass, and whole-crop corn silage $[5,6]$, very little information is available on fermentation of corn stover silage at different exposure stages. As a part of the research related to effective utilization of corn stover, our previous study using different cultivars of corn confirmed that with increasing field exposure of corn stover, the nutrient and in vitro digestibility decreased [7]. Whether microbe additives can improve silage fermentation and nutrition value of corn stover silage requires future study. In this study, we prepared corn stover silage during field exposure using LAB and cellulase and evaluated the characteristics of the resulting fermentation.

\section{MATERIALS AND METHODS}

\section{Material and ensilage}

The corn (Zea mays L.) that is widely cultivated in northeastern China was selected for use in this experiment. The cultivation experiment was carried out in an experimental field $\left(125.4^{\circ} \mathrm{E}, 43.9^{\circ} \mathrm{N}\right.$, Changchun, China). Seeds were sown on May 5, 2016, and weeds were removed by application of herbicide on May 25, 2016.

Corn ears including cobs and shucks were harvested at the ripe stage on September 26, 2016. The corn stover was exposed in the field under natural weather conditions. During the experiment, the average temperature was $3^{\circ} \mathrm{C}$, and the average air humidity was $71.3 \%$. Silages were prepared after $0,2,4,7,15,30$, and $60 \mathrm{~d}$ of exposure. The corn stover with $0,2,4$, and $7 \mathrm{~d}$ of exposure was prepared directly, and the corn stover exposed for 15,30 , and $60 \mathrm{~d}$ was adjusted to $60 \%$ moisture for producing silage. The weighed LAB, cellulose, and $\mathrm{LAB}+$ cellulase were dissolved in $20 \mathrm{~mL}$ of distilled water, uniformly sprayed on corn stover in a pot and mixed well.

Silage treatments were designed as follows: without additives (control); with LAB inoculant Chikusou-1 (LAB,
Lactobacillus plantarum, Snow Brand Seed Co., Ltd, Sapporo, Japan); with Acremonium cellulase enzyme (cellulase, Meiji Seika Pharma Co., Lte, Tokyo, Japan); or with LAB+cellulase. The LAB was inoculated at $1.0 \times 10^{5}$ colony-forming units/g of fresh matter (FM), and cellulase was applied at $50 \mathrm{mg} / \mathrm{kg}$ of FM.

Corn stover was chopped into approximately 1 to $2 \mathrm{~cm}$ lengths before ensiling and then packed into 5 liters plastic silos. The ensiling density was $550.1 \pm 20.0 \mathrm{~g} / \mathrm{L}$ of FM, and the silos were kept at room temperature $\left(10^{\circ} \mathrm{C}\right.$ to $\left.25^{\circ} \mathrm{C}\right)$. After 45 $\mathrm{d}$ of fermentation, three replicate silos were opened for chemical composition, fermentation quality and in vitro digestion analyses.

\section{Chemical analysis}

Dry matter $(\mathrm{DM})$ of fresh samples and silage were determined by oven drying at $65^{\circ} \mathrm{C}$ for $48 \mathrm{~h}$. Then, these oven-dried samples were milled through a $1.0 \mathrm{~mm}$ screen for chemical analyses. Organic matter (OM), crude protein $(\mathrm{CP})$, and ether extract (EE) were analyzed according to the methods of the Association of Official Analytical Chemists [8]. Neutral detergent fiber (NDF), acid detergent fiber (ADF) and acid detergent lignin (ADL) were determined according to Van Soest et al [9]. WSC was determined using the sulfuric acidanthrone method [10]. Buffering capacity (BC) was measured by the method of Playne and McDonald [11]. Gross energy (GE) was determined by oxygen bomb calorimeter [8]. Digestive energy (DE), metabolizable energy (ME), net energy for maintenance (NEm), net energy for lactating cows (NEl), and net energy for gain (NEg) were calculated using the following formulas.

$$
\begin{aligned}
\mathrm{DE}=\mathrm{GE} \times & {[70.19-1.364 \times(\mathrm{ADF}-29.83)-3.94+0.104} \\
& \times \mathrm{CP}+0.149 \times \mathrm{EE}+0.022 \times \mathrm{NDF}-0.244 \times \mathrm{ash}] / 100
\end{aligned}
$$

This formula was based on 347 experimental data from France and other countries, some of which came from castrated rams fed separately from hay and a mixture of hay and concentrate and some from studies that fed 50,070 dairy cows different ratios of fine and coarse mixed diets. The crude fiber (CF) content in the feed varied from 130 to $410 \mathrm{~g} / \mathrm{kg}$ (mean $243 \mathrm{~g} / \mathrm{kg}$ ), and the total protein content was 86 to $330 \mathrm{~g} / \mathrm{kg}$ (mean $166 \mathrm{~g} / \mathrm{kg}$ ). This formula has been accurately verified by the results of trials with castrated rams fed 17 different diets. The following formulas were also derived from the above formula [12].

$$
\begin{aligned}
& \mathrm{ME}=\mathrm{DE} \times[86.38-(9.9 \times \mathrm{CF}+19.6 \times \mathrm{CP}) /(100-\mathrm{ash})] / 100 \\
& \mathrm{NEm}=\mathrm{ME} \times(0.287 \times \mathrm{ME} / \mathrm{GE}+0.554) \\
& \mathrm{NEl}=\mathrm{ME} \times(0.24 \times \mathrm{ME} / \mathrm{GE}+0.463)
\end{aligned}
$$




$$
\mathrm{NEg}=\mathrm{ME} \times(0.78 \times \mathrm{ME} / \mathrm{GE}+0.006)
$$

Herein, except for CF (g/kg), CP, EE, NDF, ADF, and Ash are expressed as a percentage of $\mathrm{DM}(\% \mathrm{DM})$; the unit of $\mathrm{DE}$, $\mathrm{ME}, \mathrm{NEm}, \mathrm{NEl}$, and NEg is $\mathrm{kJ} / \mathrm{g}$ of $\mathrm{DM}$.

\section{Fermentation analysis}

Twenty grams of each silage sample were homogenized in a blender with $180 \mathrm{~mL}$ of distilled water for $1 \mathrm{~min}$ and then filtered through four layers of cheesecloth as described by Owens et al [13]. The filtrate was used to measure pH (PHSJ4F; INESA Co. Ltd., Shanghai, China), ammonia nitrogen (ammonia-N) and organic acid contents. The ammonia-N concentration was determined by Robinson [14]. The organic acid contents, including lactic acid (LA), acetic acid (AA), propionic acid (PA), and butyric acid (BA), were determined by high-performance liquid chromatography (column: Shodex RS Pak KC-811; Showa Denko K. K., Kawasaki, Japan; detector: DAD, 210 nm, SPD-20A; Shimadzu Co., Ltd, Kyoto Japan; eluent: $3 \mathrm{mmol} / \mathrm{L} \mathrm{HCLO}_{4}, 1.0 \mathrm{~mL} / \mathrm{min}$; temperature: $\left.50^{\circ} \mathrm{C}\right)$.

\section{In vitro digestibility}

The in vitro DM digestibility (IVDMD) was measured (0.5 g DM per sample) by a two-step approach [15] using ruminal liquor from sheep fed alfalfa hay and whole-plant corn silage once a day. Rumen fluid was collected through the rumen cannulas $2 \mathrm{~h}$ after feeding and diverted to plastic bottles. The fluid was filtered through 4 layers of cheesecloth and combined on an equal volume basis. The combined filtrate was mixed with $\mathrm{CO}_{2}$-bubbled $\mathrm{McD}$ Dougall's artificial saliva at a ratio of $1: 4(\mathrm{vol} / \mathrm{vol})$, and the $\mathrm{pH}$ of the artificial saliva was 6.8 . Then, $50 \mathrm{~mL}$ of buffered rumen fluid was transferred to $128 \mathrm{~mL}$ serum bottles containing $0.5 \mathrm{~g}$ of sample and flushed with $\mathrm{O}_{2}$-free $\mathrm{CO}_{2}$. Tubes were capped with a butyl rubber stopper and sealed with an aluminum cap. Incubations were performed at $39^{\circ} \mathrm{C}$ for $6 \mathrm{~h}$ in a water bath with a reciprocal shaker (100 strokes/min). Then, after this procedure, measuring the concentrations of $\mathrm{OM}, \mathrm{CP}$, and GE [8] in the indigestible residue left in the test tubes allowed the estimation of the in vitro OM digestibility (IVOMD), in vitro CP digestibility (IVCPD), and in vitro GE digestibility (IVGED) [16].

\section{Animal care}

Animal experiments were approved by the Committee of Animal Experimentation and were performed under the institutional guidelines for animal experiments of the College of Animal Science, Jilin University, China. The experiments were performed according to recommendations proposed by the European Commission to minimize the suffering of animals.

\section{Statistical analysis}

All data from this experiment were subjected to analysis with SAS ver. 9.1 (SAS Institute, Cary, NC, USA). For the chemical compositions, $\mathrm{BC}$, energy, and in vitro digestibility of corn stover, the significance differences among means were first analyzed using one-way analysis of variance (ANOVA), followed by Duncan's test for significance between means. Linear, quadratic, cubic, logarithmic, monomial, and exponential regression models were fitted to describe the relationship between days of exposure and measurements. All the regression models for all measurements were shown to be extremely significant $(\mathrm{p}<0.005)$, so the $\mathrm{p}$ value was not presented for each model in Table 1,2. Data on the chemical composition, energy, fermentation quality, and in vitro digestibility of silage were analyzed using 3-factor ANOVA, with exposure $d(D)$, additive LAB (A), and additive cellulase (B) as fixed factors. The main effect of each factor and the interactions between factors were analyzed. While the interaction between $\mathrm{A}$ and $B$ was significant, levels of $A$ and $B$ were combined to a new factor $(A+B)$ with 4 levels: no additives, LAB added, cellulase added, and both $\mathrm{LAB}+$ cellulase added. Then, the two-way ANOVA was used to test the main effects and interactions of exposure $\mathrm{d}(\mathrm{D})$ and $\mathrm{AB}$. The contrasts between the main effects of marginal means were made with the least significant difference method.

\section{RESULTS}

The chemical composition, $\mathrm{BC}$, energy, and in vitro digestibility of corn stover, and the coefficient of determination for each regression equation $\left(R^{2}\right)$ during field exposure are shown in Table 1, 2. The DM, CP, NDF, and WSC values of fresh corn stover at $0 \mathrm{~d}$ of exposure were $21.91 \%, 9.01 \%, 64.54 \%$, and $8.42 \%$ of $\mathrm{DM}$, respectively. As the field exposure time increased, the DM, OM, NDF, ADF, and ADL contents significantly $(\mathrm{p}<0.05)$ increased in corn stover; however, the CP, WSC, DE, ME, NEm, NEl, NEg, and BC levels significantly $(\mathrm{p}<0.05)$ decreased. At $60 \mathrm{~d}$ of exposure, the CP, WSC, and DE decreased to $5.03,3.41$, and $7.98 \mathrm{MJ} / \mathrm{kg}$ of DM, respectively. As the field exposure time increased, the IVDMD, IVOMD, IVCPD, and IVGED of corn stover decreased significantly $(\mathrm{p}<0.05)$.

The chemical composition and energy of corn stover silage prepared with LAB and cellulase are shown in Table 3, 4. As the field exposure time increased, the $\mathrm{CP}$ content and GE, DE, $\mathrm{ME}, \mathrm{NEm}, \mathrm{NEl}$, and NEg levels significantly $(\mathrm{p}<0.05)$ decreased, while NDF, ADF, and ADL contents significantly ( $\mathrm{p}<$ 0.05 ) increased. Exposure d (D) influenced all chemical composition and energy measurements $(\mathrm{p}=0.000)$, and LAB treatment of silage influenced the OM $(\mathrm{p}=0.025)$. Cellulase treatment of silage influenced the NDF, $\mathrm{ADF}, \mathrm{DE}, \mathrm{ME}, \mathrm{NEm}$, $\mathrm{NEl}$, and $\mathrm{NEg}(\mathrm{p}=0.002-0.008)$. $\mathrm{D} \times \mathrm{LAB}$ influenced the $\mathrm{DM}$, 
Table 1. Chemical composition and buffering capacity of corn stover during field exposure

\begin{tabular}{|c|c|c|c|c|c|c|c|c|}
\hline \multirow{2}{*}{ Exposure $d$} & \multirow{2}{*}{ DM (\%) } & OM & $\mathrm{CP}$ & NDF & ADF & ADL & WSC & \multirow{2}{*}{$\begin{array}{c}\mathrm{BC} \\
(\mathrm{mE} / \mathrm{kg} \text { of } \mathrm{DM})\end{array}$} \\
\hline & & \multicolumn{6}{|c|}{ 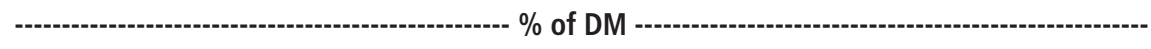 } & \\
\hline 0 & $21.91^{9}$ & $90.38^{\mathrm{d}}$ & $9.01^{\mathrm{a}}$ & $64.54^{\dagger}$ & $35.92^{f}$ & $4.93^{\mathrm{d}}$ & $8.42^{\mathrm{a}}$ & $266.62^{\mathrm{a}}$ \\
\hline 2 & $29.73^{f}$ & $91.37^{c}$ & $7.02^{b}$ & $66.48^{e}$ & $40.13^{e}$ & $6.21^{c}$ & $7.33^{b}$ & $197.05^{c}$ \\
\hline 4 & $31.12^{\mathrm{e}}$ & $93.60^{b}$ & $7.25^{b}$ & $70.73^{d}$ & $42.86^{d}$ & $6.96^{\mathrm{bc}}$ & $6.02^{c}$ & $228.47^{b}$ \\
\hline 7 & $35.72^{d}$ & $94.99^{\mathrm{a}}$ & $5.99^{c}$ & $70.73^{d}$ & $42.86^{d}$ & $6.05^{\mathrm{cd}}$ & $4.73^{d}$ & $203.58^{c}$ \\
\hline 15 & $47.13^{c}$ & $94.81^{\mathrm{a}}$ & $5.67^{d}$ & $77.92^{c}$ & $48.75^{c}$ & $8.14^{\mathrm{ab}}$ & $4.16^{\mathrm{e}}$ & $167.36^{d}$ \\
\hline 30 & $71.35^{b}$ & $95.39^{a}$ & $5.01^{\mathrm{e}}$ & $80.18^{b}$ & $51.39^{b}$ & $8.04^{\mathrm{ab}}$ & $3.41^{\dagger}$ & $173.02^{d}$ \\
\hline 60 & $88.20^{a}$ & $95.12^{a}$ & $5.03^{e}$ & $82.10^{a}$ & $53.32^{\mathrm{a}}$ & $8.98^{\mathrm{a}}$ & $3.41^{\dagger}$ & $128.61^{e}$ \\
\hline SEM & 0.14 & 0.31 & 0.08 & 0.54 & 0.39 & 0.38 & 0.02 & 4.19 \\
\hline \multicolumn{9}{|c|}{ Coefficient of determination $\left(R^{2}\right)$ of regression equation $(p<0.005)$} \\
\hline Linear & 0.9319 & 0.3652 & 0.5168 & 0.7342 & 0.7395 & 0.6890 & 0.5453 & 0.6922 \\
\hline Quadratic & 0.9767 & 0.6857 & 0.7934 & 0.9498 & 0.9423 & 0.8181 & 0.8462 & 0.7574 \\
\hline Cubic & 0.9869 & 0.8693 & 0.8911 & 0.9898 & 0.9856 & 0.9000 & 0.9557 & 0.8650 \\
\hline Logarithmic & 0.7911 & 0.7792 & 0.8996 & 0.9544 & 0.9830 & 0.8992 & 0.9199 & 0.8628 \\
\hline Monomial & 0.7199 & 0.7782 & 0.9266 & 0.9561 & 0.9826 & 0.8904 & 0.9417 & 0.8581 \\
\hline Exponential & 0.9904 & 0.3631 & 0.5798 & 0.7136 & 0.6982 & 0.6237 & 0.6272 & 0.7833 \\
\hline
\end{tabular}

Data are means of the three silage samples.

DM, dry matter; OM, organic matter; CP, crude protein; NDF, neutral detergent fiber; ADF, acid detergent fiber; ADL, acid detergent lignin; WSC, water soluble carbohydrate; BC, buffering capacity; SEM, standard error of mean.

${ }^{a-g}$ Means within columns with different superscript letters differ significantly from each other $(p<0.05)$.

$\mathrm{OM}$, and $\mathrm{CP}(\mathrm{p}=0.000-0.002)$. Dxcellulase influenced DM and GE $(\mathrm{p}=0.000$ and 0.001$)$. LAB $\times$ cellulase influenced DM and GE $(\mathrm{p}=0.005$ and 0.002$)$. $\mathrm{D} \times \mathrm{LAB} \times$ cellulase influenced $\mathrm{DM}, \mathrm{OM}$, and $\mathrm{CP}(\mathrm{p}=0.000-0.009)$.

The fermentation characteristics of corn stover silage prepared with LAB and cellulase are shown in Table 5. Silages prepared under all treatments were well preserved, with $\mathrm{pH}$ values below 4.10. As the field exposure time increased, corn stover silage $\mathrm{pH}$ increased significantly $(\mathrm{p}<0.05)$, but PA content decreased significantly $(\mathrm{p}<0.05)$. The LA and AA contents of corn stover silage were significantly $(\mathrm{p}<0.05)$ higher at 0 to $4 \mathrm{~d}$ of exposure than at 7 to $60 \mathrm{~d}$ of exposure. In LAB, cellulase or $\mathrm{LAB}+$ cellulase-treated silages, the $\mathrm{pH}$ was lower $(\mathrm{p}<$ $0.05)$, and LA and AA contents were higher $(\mathrm{p}<0.05)$ than

Table 2. Energy and in vitro digestibility of corn stover during field exposure

\begin{tabular}{|c|c|c|c|c|c|c|c|c|c|c|}
\hline \multirow{2}{*}{ Exposure $d$} & \multicolumn{6}{|c|}{ Energy (MJ/kg of DM) } & \multicolumn{4}{|c|}{ In vitro digestibility ( $\%$ of DM) } \\
\hline & GE & $\mathrm{DE}$ & ME & NEm & NEI & NEg & IVDMD & IVOMD & IVCPD & IVGED \\
\hline 0 & $18.97^{\mathrm{e}}$ & $11.92^{\mathrm{a}}$ & $9.66^{\mathrm{a}}$ & $6.76^{\mathrm{a}}$ & $5.66^{\mathrm{a}}$ & $3.90^{\mathrm{a}}$ & $52.16^{a}$ & $56.69^{a}$ & $50.52^{\mathrm{a}}$ & $55.07^{\mathrm{a}}$ \\
\hline 2 & $19.19^{\text {cd }}$ & $10.99^{b}$ & $8.91^{b}$ & $6.12^{b}$ & $5.12^{b}$ & $3.28^{b}$ & $49.74^{b}$ & $54.12^{b}$ & $47.72^{b}$ & $52.99^{b}$ \\
\hline 4 & $19.07^{\text {de }}$ & $10.20^{c}$ & $8.25^{c}$ & $5.59^{c}$ & $4.68^{c}$ & $2.83^{c}$ & $47.83^{c}$ & $52.16^{c}$ & $47.27^{c}$ & $52.25^{c}$ \\
\hline 7 & $19.29^{c}$ & $10.38^{c}$ & $8.44^{c}$ & $5.73^{c}$ & $4.79^{c}$ & $2.93^{c}$ & $48.39^{c}$ & $52.69^{c}$ & $46.15^{d}$ & $52.03^{c}$ \\
\hline 15 & $19.82^{b}$ & $9.17^{d}$ & $7.43^{d}$ & $4.91^{\mathrm{d}}$ & $4.11^{d}$ & $2.22^{d}$ & $45.49^{d}$ & $49.15^{d}$ & $44.43^{e}$ & $49.05^{d}$ \\
\hline 30 & $20.02^{\mathrm{a}}$ & $8.59^{e}$ & $6.95^{\mathrm{e}}$ & $4.54^{\mathrm{e}}$ & $3.80^{\mathrm{e}}$ & $1.93^{\mathrm{e}}$ & $44.21^{\mathrm{e}}$ & $47.71^{\mathrm{e}}$ & $43.21^{\dagger}$ & $44.99^{\mathrm{e}}$ \\
\hline 60 & $19.86^{b}$ & $7.98^{f}$ & $6.46^{f}$ & $4.18^{f}$ & $3.50^{\dagger}$ & $1.68^{f}$ & $42.78^{f}$ & $46.28^{f}$ & $42.76^{9}$ & $46.62^{f}$ \\
\hline SEM & 0.04 & 0.09 & 0.08 & 0.06 & 0.05 & 0.05 & 0.23 & 0.26 & 0.11 & 0.23 \\
\hline \multicolumn{11}{|c|}{ Coefficient of determination $\left(R^{2}\right)$ of regression equation $(p<0.005)$} \\
\hline Linear & 0.5850 & 0.7586 & 0.7582 & 0.7409 & 0.7409 & 0.7020 & 0.7414 & 0.7442 & 0.6560 & 0.7471 \\
\hline Quadratic & 0.9516 & 0.9257 & 0.9249 & 0.9194 & 0.9194 & 0.9067 & 0.9112 & 0.9260 & 0.8996 & 0.9088 \\
\hline Cubic & 0.9580 & 0.9742 & 0.9720 & 0.9711 & 0.9711 & 0.9688 & 0.9668 & 0.9744 & 0.9674 & 0.9600 \\
\hline Logarithmic & 0.8310 & 0.9850 & 0.9824 & 0.9828 & 0.9828 & 0.9805 & 0.9829 & 0.9808 & 0.9789 & 0.9711 \\
\hline Monomial & 0.8326 & 0.9810 & 0.9784 & 0.9798 & 0.9798 & 0.9788 & 0.9830 & 0.9798 & 0.9825 & 0.9707 \\
\hline Exponential & 0.5848 & 0.8034 & 0.8029 & 0.7945 & 0.7945 & 0.7947 & 0.7648 & 0.7663 & 0.6752 & 0.7660 \\
\hline
\end{tabular}

Data are means of the three silage samples.

DM, dry matter; GE, gross energy; DE, digestible energy; ME, metabolizable energy; NEm, net energy for maintenance; NEl, net energy for lactating cow; NEg, net energy for gain; IVDMD, in vitro dry matter digestibility; IVOMD, in vitro organic matter digestibility; IVCPD, in vitro crude protein digestibility; IVGED, in vitro gross energy digestibility; SEM, standard error of mean.

${ }^{a-g}$ Means within columns with different superscript letters differ significantly from each other $(p<0.05)$. 
Table 3. Chemical compositions of corn stover silage prepared with lactic acid bacteria and cellulase

\begin{tabular}{|c|c|c|c|c|c|c|}
\hline \multirow{2}{*}{ Items } & \multirow{2}{*}{ DM \% } & OM & $\mathrm{CP}$ & NDF & ADF & $A D L$ \\
\hline & & \multicolumn{5}{|c|}{ 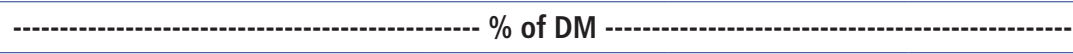 } \\
\hline \multicolumn{7}{|l|}{ Exposure $\mathrm{d}$ means } \\
\hline 0 & $21.31^{\mathrm{a}}$ & $90.35^{\mathrm{a}}$ & $7.66^{\mathrm{e}}$ & $67.62^{a}$ & $40.49^{a}$ & $6.02^{\mathrm{a}}$ \\
\hline 2 & $21.28^{\mathrm{a}}$ & $90.24^{\mathrm{a}}$ & $7.09^{d}$ & $70.50^{b}$ & $43.55^{b}$ & $6.75^{b}$ \\
\hline 4 & $27.01^{b}$ & $91.57^{b}$ & $7.15^{d}$ & $72.47^{c}$ & $45.44^{c}$ & $7.41^{c}$ \\
\hline 7 & $27.74^{c}$ & $92.83^{c}$ & $6.41^{c}$ & $74.19^{d}$ & $46.05^{c}$ & $7.21^{b c}$ \\
\hline 15 & $34.81^{e}$ & $93.35^{d}$ & $6.05^{b}$ & $76.17^{\mathrm{e}}$ & $47.32^{d}$ & $7.67^{c}$ \\
\hline 30 & $34.41^{d}$ & $94.53^{f}$ & $5.31^{\mathrm{a}}$ & $77.54^{\dagger}$ & $50.17^{e}$ & $8.98^{d}$ \\
\hline 60 & $36.28^{f}$ & $94.22^{e}$ & $5.49^{\mathrm{a}}$ & $77.88^{f}$ & $50.12^{e}$ & $9.28^{d}$ \\
\hline SEM & 0.14 & 0.06 & 0.12 & 0.46 & 0.40 & 0.17 \\
\hline \multicolumn{7}{|l|}{ Additives means } \\
\hline Control & $29.01^{\mathrm{ab}}$ & $92.53^{b}$ & $6.35^{\mathrm{a}}$ & $74.39^{b}$ & $46.72^{b}$ & 7.74 \\
\hline$L A B$ & $28.81^{\mathrm{a}}$ & $92.44^{\mathrm{ab}}$ & $6.23^{\mathrm{a}}$ & $74.16^{\mathrm{ab}}$ & $46.43^{b}$ & 7.54 \\
\hline Cellulase & $28.83^{\mathrm{a}}$ & $92.46^{\mathrm{ab}}$ & $6.41^{\mathrm{ab}}$ & $73.14^{\mathrm{a}}$ & $45.45^{\mathrm{a}}$ & 7.47 \\
\hline LAB+cellulase & $29.25^{b}$ & $92.33^{\mathrm{a}}$ & $6.63^{b}$ & $73.39^{a b}$ & $46.04^{\mathrm{ab}}$ & 7.72 \\
\hline SEM & 0.11 & 0.05 & 0.09 & 0.35 & 0.30 & 0.13 \\
\hline \multicolumn{7}{|c|}{ Significance of main effects and interactions } \\
\hline Exposure d (D) & 0.000 & 0.000 & 0.000 & 0.000 & 0.000 & 0.000 \\
\hline$L A B$ & 0.316 & 0.025 & 0.530 & 0.987 & 0.610 & 0.824 \\
\hline Cellulase & 0.249 & 0.065 & 0.012 & 0.006 & 0.008 & 0.708 \\
\hline$D \times L A B$ & 0.000 & 0.002 & 0.001 & 0.695 & 0.636 & 0.447 \\
\hline D $\times$ cellulase & 0.000 & 0.043 & 0.818 & 0.956 & 0.970 & 0.191 \\
\hline $\mathrm{LAB} \times$ cellulase & 0.005 & 0.725 & 0.058 & 0.498 & 0.147 & 0.079 \\
\hline $\mathrm{D} \times \mathrm{LAB} \times$ cellulase & 0.000 & 0.000 & 0.009 & 0.045 & 0.015 & 0.191 \\
\hline
\end{tabular}

Data are means of the three silage samples.

DM, dry matter; OM, organic matter; CP, crude protein; NDF, neutral detergent fiber; ADF, acid detergent fiber; $A D L$, acid detergent lignin; SEM, standard error of mean; LAB, lactic acid bacteria.

${ }^{a-f}$ Means within columns with different superscript letters differ significantly from each other $(p<0.05)$.

those of the control, whereas the rates of ammonia-N/total $\mathrm{N}$ were not significantly different among treatments. $\mathrm{D}$ influenced all fermentation quality parameters $(\mathrm{p}=0.000)$, and $\mathrm{LAB}$ treatment influenced LA and AA $(\mathrm{p}=0.000)$. Cellulase treatment influenced $\mathrm{pH}, \mathrm{LA}, \mathrm{AA}$, and $\mathrm{BA}(\mathrm{p}=0.000-0.004)$. $\mathrm{D} \times \mathrm{LAB}$ influenced $\mathrm{LA}, \mathrm{AA}$, and BA contents and ammonia$\mathrm{N} / \mathrm{TN}(\mathrm{p}=0.000)$. D $\times$ cellulase influenced $\mathrm{pH}$ and $\mathrm{AA}(\mathrm{p}=$ $0.000)$. LAB $\times$ cellulase influenced DM and GE ( $p=0.005$ and

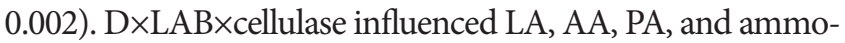
nia-N/TN ( $\mathrm{p}=0.000-0.002)$.

The in vitro digestibility of corn stover silage prepared with LAB and cellulase is shown in Table 6. As the field exposure time increased, the IVDMD, IVOMD, IVCPD, and IVGED decreased $(p<0.05)$. The IVDMD and IVCPD levels were higher $(\mathrm{p}<0.05)$ in cellulase- and LAB+cellulase-treated silages than in the control and LAB-treated silage. D and cellulase treatment influenced all measures in vitro digestibility $(\mathrm{p}=$ 0.000-0.003). $\mathrm{D} \times \mathrm{LAB}$ and $\mathrm{D} \times \mathrm{LAB} \times$ cellulase influenced IVCPD ( $p=0.004$ and 0.000$)$, but LAB and other interactions did not.

\section{DISCUSSION}

Generally, as field exposure time increased, corn stover experienced moisture loss, whereas the proportion of DM increased significantly, and NDF, ADF, and ADL contents increased drastically [17]. These results are consistent with those of our study. We also demonstrated higher levels of NDF, ADF, and ADL components in corn stover, which further resulted in decreased IVDMD and DE, which were negatively correlated with cell wall structural components such as cellulose and lignin.

The WSC and CP content in corn stover also decreased significantly with exposure time (Table 1) due to the loss of feed nutrients, including noncellulosic saccharides. Aerobic spoilage bacteria present in the stover and plant respiration consume nutrients such as proteins and sugars in plants [18]; these processes are important factors contributing to the reduction in DE observed in this study. Sun et al [7] reported that fresh corn stover contained a relatively high LAB count and WSC content, and the resulting silage fermented well, with minimal nutrient loss and improved in vitro digestibility. Usually, fresh stover had a relatively low DM while high WSC content and LAB counts, result in the silage prepared as good quality, but the dry stover did not [7]. In agreement 
Table 4. Energy of corn stover silage prepared with lactic acid bacteria and cellulase

\begin{tabular}{|c|c|c|c|c|c|c|}
\hline \multirow{2}{*}{ Items } & GE & $\mathrm{DE}$ & ME & NEm & NEI & NEg \\
\hline & \multicolumn{6}{|c|}{ 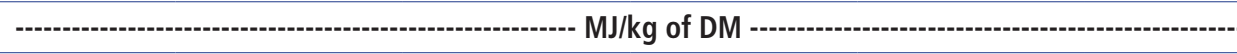 } \\
\hline \multicolumn{7}{|l|}{ Exposure $\mathrm{d}$ means } \\
\hline 0 & $19.70^{b}$ & $11.24^{d}$ & $9.09^{d}$ & $6.24^{d}$ & $5.22^{d}$ & $3.33^{d}$ \\
\hline 2 & $20.27^{c}$ & $10.79^{c}$ & $8.73^{c}$ & $5.92^{c}$ & $4.95^{c}$ & $2.99^{c}$ \\
\hline 4 & $19.70^{b}$ & $9.94^{b}$ & $8.04^{b}$ & $5.40^{b}$ & $4.51^{b}$ & $2.61^{b}$ \\
\hline 7 & $19.73^{b}$ & $9.81^{b}$ & $7.94^{b}$ & $5.31^{b}$ & $4.44^{b}$ & $2.54^{b}$ \\
\hline 15 & $20.23^{c}$ & $9.79^{b}$ & $7.90^{b}$ & $5.27^{b}$ & $4.40^{b}$ & $2.46^{b}$ \\
\hline 30 & $18.98^{\mathrm{a}}$ & $8.30^{\mathrm{a}}$ & $6.69^{\mathrm{a}}$ & $4.39^{\mathrm{a}}$ & $3.67^{\mathrm{a}}$ & $1.88^{\mathrm{a}}$ \\
\hline 60 & $18.91^{\mathrm{a}}$ & $8.26^{\mathrm{a}}$ & $6.66^{\mathrm{a}}$ & $4.36^{\mathrm{a}}$ & $3.65^{\mathrm{a}}$ & $1.87^{\mathrm{a}}$ \\
\hline SEM & 0.05 & 0.11 & 0.09 & 0.07 & 0.06 & 0.06 \\
\hline \multicolumn{7}{|l|}{ Additives means } \\
\hline Control & $19.68^{b}$ & $9.61^{\mathrm{a}}$ & $7.76^{\mathrm{a}}$ & $5.18^{\mathrm{a}}$ & $4.33^{\mathrm{a}}$ & $2.45^{\mathrm{a}}$ \\
\hline$L A B$ & $19.54^{\mathrm{a}}$ & $9.59^{\mathrm{a}}$ & $7.76^{\mathrm{a}}$ & $5.19^{\mathrm{a}}$ & $4.34^{\mathrm{a}}$ & $2.47^{\mathrm{a}}$ \\
\hline Cellulase & $19.63^{b}$ & $9.91^{b}$ & $8.01^{b}$ & $5.39^{b}$ & $4.51^{b}$ & $2.63^{b}$ \\
\hline LAB+cellulase & $19.72^{b}$ & $9.81^{\mathrm{ab}}$ & $7.93^{\mathrm{ab}}$ & $5.32^{\mathrm{ab}}$ & $4.44^{\mathrm{ab}}$ & $2.55^{\mathrm{ab}}$ \\
\hline SEM & 0.04 & 0.08 & 0.07 & 0.05 & 0.04 & 0.04 \\
\hline \multicolumn{7}{|c|}{ Significance of main effects and interactions } \\
\hline Exposure d (D) & 0.000 & 0.000 & 0.000 & 0.000 & 0.000 & 0.000 \\
\hline$L A B$ & 0.502 & 0.488 & 0.520 & 0.521 & 0.521 & 0.527 \\
\hline Cellulase & 0.079 & 0.002 & 0.002 & 0.002 & 0.002 & 0.004 \\
\hline$D \times L A B$ & 0.027 & 0.624 & 0.708 & 0.718 & 0.718 & 0.725 \\
\hline D $\times$ cellulase & 0.001 & 0.693 & 0.684 & 0.741 & 0.741 & 0.838 \\
\hline LAB $\times$ cellulase & 0.002 & 0.596 & 0.527 & 0.430 & 0.430 & 0.253 \\
\hline $\mathrm{D} \times \mathrm{LAB} \times$ cellulase & 0.083 & 0.039 & 0.052 & 0.040 & 0.040 & 0.020 \\
\hline
\end{tabular}

Data are means of the three silage samples.

$\mathrm{DM}$, dry matter; GE, gross energy; DE, digestible energy; ME, metabolizable energy; NEm, net energy for maintenance; NEl, net energy for lactating cow; NEg, net energy for gain; SEM, standard error of mean; LAB, lactic acid bacteria.

${ }_{a-d}$ Means within columns with different superscript letters differ significantly from each other $(p<0.05)$.

with the previous studies, with increasing field exposure of corn stover, the CP and WSC contents and in vitro digestibility decreased. Therefore, fresh corn stover has suitable ensiling characteristics, and that silage should be prepared immediately after harvesting corn.

Generally, as grasses grow to maturity, DM, NDF, ADF, and ADL levels increase, whereas WSC, CP, and EE levels decrease [19]. Silage material is typically required to contain at least $5 \%$ WSC DM for high-quality fermentation. Harvesting and exposure time greatly influence the chemical composition of forage; both WSC and BC contents tended to vary considerably [20], indicating that exposure time may change the chemical composition of the materials and influence silage fermentation quality.

In the current study, the NDF and ADF content was significantly lower in cellulase-treated silage than in control silage because the applied cellulase mainly degraded plant fiber (NDF and ADF) to increase WSC as a substrate for LAB to produce LA and improve silage fermentation [21]. The chemical composition did not differ significantly between silage treated with and without LAB and was similar across treatments at the same exposure time. It is likely that forage corn, including stover, has good ensilage characteristics, such that good silage fermentation preserves nutrients well.

Factors used to assess fermentation quality include the physiological properties of epiphytic LAB and fermentation products. Epiphytic LAB can reduce $\mathrm{pH}$ by synthesizing LA, inhibiting the activity of bacteria, fungi or plant enzymes, and decreasing microbial diversity, resulting in improved silage fermentation without the addition of LAB. Thus, goodquality silage fermentation slows the reaction process of protein degradation to form nonprotein nitrogen, ammonia nitrogen and volatile fatty acids, greatly preserving the $\mathrm{CP}$ and EE during ensilage [22]. Zhang et al [23] also found that in the anaerobic environment of natural fermentation, the conversion of WSC to LA allowed epiphytic LAB to lower the $\mathrm{pH}$, which is consistent with the results of this experiment.

In cellulase-treated silage, $\mathrm{ME}$ and NEm levels were higher than those of the control silage, whereas NDF and ADF contents and the levels of other factors were lower (Table 3). This result demonstrates that cellulase could both reduce indigestible cellulosic materials and improve feed digestion and metabolism. It is worth noting that it could not be used alone in actual production because the $\mathrm{CP}$ and effective energy value 
Table 5. Fermentation quality of corn stover silage prepared with lactic acid bacteria and cellulase

\begin{tabular}{|c|c|c|c|c|c|c|}
\hline \multirow{2}{*}{ Items } & \multirow{2}{*}{$\mathrm{pH}$} & LA & AA & PA & BA & \multirow{2}{*}{$\begin{array}{c}\text { Ammonia-N/TN } \\
(\%)\end{array}$} \\
\hline & & \multicolumn{4}{|c|}{ 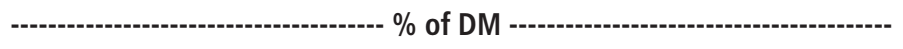 } & \\
\hline \multicolumn{7}{|l|}{ Exposure d means } \\
\hline 0 & $3.59^{\mathrm{a}}$ & $8.15^{d}$ & $9.76^{\mathrm{e}}$ & $0.87^{b}$ & $0.18^{e}$ & $2.26^{\mathrm{a}}$ \\
\hline 2 & $3.59^{\mathrm{a}}$ & $7.18^{c}$ & $6.68^{c}$ & $0.94^{b}$ & $0.16^{d}$ & $2.37^{c}$ \\
\hline 4 & $3.99^{c}$ & $8.07^{d}$ & $8.21^{\mathrm{d}}$ & $0.35^{\mathrm{a}}$ & $0.12^{\mathrm{a}}$ & $1.66^{\mathrm{a}}$ \\
\hline 7 & $4.00^{c}$ & $6.23^{b}$ & $5.47^{b}$ & $0.25^{\mathrm{a}}$ & $0.17^{\mathrm{de}}$ & $2.17^{\mathrm{bc}}$ \\
\hline 15 & $3.85^{b}$ & $5.96^{b}$ & $1.07^{\mathrm{a}}$ & $0.13^{\mathrm{a}}$ & $0.14^{\mathrm{bc}}$ & $2.10^{\mathrm{bc}}$ \\
\hline 30 & $3.98^{c}$ & $3.59^{\mathrm{a}}$ & $1.30^{\mathrm{a}}$ & $0.18^{\mathrm{a}}$ & $0.13^{\mathrm{ab}}$ & $2.29^{b c}$ \\
\hline 60 & $4.05^{d}$ & $3.41^{\mathrm{a}}$ & $1.58^{\mathrm{a}}$ & $0.19^{a}$ & $0.15^{c}$ & $2.06^{b}$ \\
\hline SEM & 0.01 & 0.20 & 0.22 & 0.09 & 0.01 & 0.09 \\
\hline \multicolumn{7}{|l|}{ Additives means } \\
\hline Control & $3.91^{c}$ & $5.20^{\mathrm{a}}$ & $3.66^{\mathrm{a}}$ & $0.28^{\mathrm{a}}$ & $0.16^{b}$ & $2.17^{\mathrm{ab}}$ \\
\hline$L A B$ & $3.87^{b}$ & $6.19^{b}$ & $5.32^{b c}$ & $0.58^{b}$ & $0.16^{b}$ & $2.25^{b}$ \\
\hline Cellulase & $3.84^{\mathrm{a}}$ & $6.16^{b}$ & $4.87^{\mathrm{b}}$ & $0.54^{\mathrm{b}}$ & $0.14^{a}$ & $2.10^{\mathrm{ab}}$ \\
\hline LAB+cellulase & $3.84^{\mathrm{a}}$ & $6.79^{c}$ & $5.62^{c}$ & $0.27^{\mathrm{a}}$ & $0.15^{b}$ & $2.00^{\mathrm{a}}$ \\
\hline SEM & 0.01 & 0.15 & 0.17 & 0.06 & 0.00 & 0.07 \\
\hline \multicolumn{7}{|c|}{ Significance of main effects and interactions } \\
\hline Exposure d (D) & 0.000 & 0.000 & 0.000 & 0.000 & 0.000 & 0.000 \\
\hline $\mathrm{LAB}$ & 0.012 & 0.000 & 0.000 & 0.851 & 0.065 & 0.889 \\
\hline Cellulase & 0.000 & 0.000 & 0.000 & 0.683 & 0.004 & 0.022 \\
\hline$D \times L A B$ & 0.195 & 0.000 & 0.000 & 0.236 & 0.000 & 0.000 \\
\hline D $\times$ cellulase & 0.000 & 0.062 & 0.000 & 0.952 & 0.045 & 0.022 \\
\hline $\mathrm{LAB} \times$ cellulase & 0.052 & 0.229 & 0.009 & 0.000 & 0.015 & 0.223 \\
\hline$D \times L A B \times$ cellulase & 0.103 & 0.000 & 0.000 & 0.000 & 0.198 & 0.002 \\
\hline
\end{tabular}

Data are means of the three silage samples.

LA, lactic acid; AA, acetic acid; PA, propionic acid; BA, butyric acid; TN, total nitrogen; DM, dry matter; SEM, standard error of mean; LAB, lactic acid bacteria.

a-e Means within columns with different superscript letters differ significantly from each other $(p<0.05)$.

of corn stover silage were low. Therefore, high-protein and high-energy feeds such as soybean meal, corn or high-quality hay should be used in combination to meet the demand for protein, NEl, and NEg in lactating cows or growing cattle when feeding cows or beef cattle with corn stover silage. In our study, D affected all chemical constituents of corn stover silage; LAB $\times$ cellulase did not affect the OM. $\mathrm{D} \times \mathrm{LAB}$ and cellulase treatment affected OM and GE levels. This result suggests that exposure time and the application of additives have a significant impact on material chemical composition and silage fermentation quality.

In all $\mathrm{LAB}$ and cellulase-treated silages, the $\mathrm{pH}$ was below 4.20 (Table 5), indicating high silage fermentation quality. As the exposure time increased, the LA content gradually decreased due to decreases in moisture and WSC content. However, the PA content of the LAB- or cellulase-treated silage was significantly higher than that of the control silage. The reason for this finding remains unclear; it may be that epiphytic propionibacteria in contact with stover material converted LA to PA and $\mathrm{CO} 2$ during ensilage. Future studies should aim to isolate and identify PA-producing bacteria.

The LA and AA content in corn stover silage was significantly higher at 0 to $2 \mathrm{~d}$ (Table 5) because the WSC of the silage material was higher at 0 to $2 \mathrm{~d}$ of exposure $(7.33 \%$ to $8.42 \%$ DM); WSC was the main substrate for LAB fermentation. Jahanzad et al [24] found that molasses, a source of WSC, can increase the activity of homofermentative LAB and convert WSC to LA.

In the present study, the LA content of LAB+cellulasetreated silage was significantly higher than that of other silage treatments due to the conversion of cellulosic material into monosaccharides by cellulase, which enhanced the growth of LAB. However, at different exposure times, silage treated with $\mathrm{LAB}$, cellulase and $\mathrm{LAB}+$ cellulase exhibited no significant differences from the control silage in ammonia-N/TN. This result could be explained by a high abundance of LAB, which can enhance fermentation quality, and by low $\mathrm{pH}$, which inhibits the growth and proteolytic activity of clostridia [25]. During ensilage, clostridia cannot degrade protein to produce ammonia-N; therefore, it is impossible to obtain large quantities of ammonia-N. In this study, exposure time, additives and their interaction affected the $\mathrm{pH}$ and organic acid content but did not affect the ammonia-N/TN of silage. Thus, exposure time and additives can influence silage fermentation quality.

High fiber content generally leads to a decline in feed IVD- 
Table 6. In vitro digestibility of corn stover silage prepared with lactic acid bacteria and cellulase

\begin{tabular}{|c|c|c|c|c|}
\hline Items & IVDMD & IVOMD & IVCPD & IVGED \\
\hline \multicolumn{5}{|l|}{ Exposure $d$ means } \\
\hline 2 & $48.72^{c}$ & $51.94^{c}$ & $46.67^{d}$ & $50.85^{c}$ \\
\hline 4 & $47.17^{b}$ & $50.84^{b}$ & $46.55^{d}$ & $50.11^{b}$ \\
\hline 7 & $46.89^{b}$ & $50.66^{b}$ & $45.75^{c}$ & $50.16^{b}$ \\
\hline 30 & $43.32^{\mathrm{a}}$ & $47.77^{\mathrm{a}}$ & $43.76^{\mathrm{a}}$ & $47.70^{a}$ \\
\hline 60 & $43.20^{\mathrm{a}}$ & $47.69^{\mathrm{a}}$ & $43.94^{\mathrm{a}}$ & $47.56^{\mathrm{a}}$ \\
\hline SEM & 0.25 & 0.26 & 0.14 & 0.24 \\
\hline \multicolumn{5}{|l|}{ Additives means } \\
\hline Control & $46.27^{\mathrm{a}}$ & $50.06^{a}$ & $45.54^{\mathrm{a}}$ & $49.54^{\mathrm{a}}$ \\
\hline \multicolumn{5}{|c|}{ Significance of main effects and interactions } \\
\hline Exposure d (D) & 0.000 & 0.000 & 0.000 & 0.000 \\
\hline $\mathrm{LAB}$ & 0.522 & 0.517 & 0.912 & 0.447 \\
\hline Cellulase & 0.001 & 0.003 & 0.000 & 0.003 \\
\hline$D \times L A B$ & 0.530 & 0.596 & 0.004 & 0.532 \\
\hline D x cellulase & 0.693 & 0.940 & 0.957 & 0.912 \\
\hline LAB $\times$ cellulase & 0.590 & 0.276 & 0.682 & 0.350 \\
\hline $\mathrm{D} \times \mathrm{LAB} \times$ cellulase & 0.023 & 0.018 & 0.000 & 0.023 \\
\hline
\end{tabular}

Data are means of the three silage samples.

IVDMD, in vitro dry matter digestibility; IVOMD, in vitro organic matter digestibility; IVCPD, in vitro crude protein digestibility; IVGED, in vitro gross energy digestibility; DM, dry matter; SEM, standard error of mean; LAB, lactic acid bacteria.

${ }^{a-e}$ Means within columns with different superscript letters differ significantly from each other $(p<0.05)$.

MD [26]. In this study, IVDMD, IVOMD, IVCPD, and IVGED levels of corn stover silage were lower than those of unfermented corn stover due to a significant increase in NDF, ADF, and ADL contents (Table 6). Santos et al [27] found that after fermentation, IVDMD decreased by an average of $21.3 \%$ in three sugarcane shoots. Therefore, IVDMD was higher in the cellulase treatment than in the control and LAB treatments. OM digestibility is a key factor reflecting the nutritional intake efficiency and production value potential of animal feed; lignin content is negatively correlated with IVOMD [28] and is considered to be a major factor affecting plant cell wall digestibility [29]. In this study, corn stalk IVDMD and IVOMD decreased significantly as exposure time increased; the corn maturity, stem-to-leaf ratio, and the degree of stover lignification also increased, leading to reduced in vitro digestibility. This result was consistent with that of corn stover silage in our study. As the exposure time was prolonged, the $\mathrm{CP}$ content and energy decreased. Rain, sunlight and microbial growth during field exposure may contribute to declines in IVCPD and IVGED.

Exposure time and cellulase affected the in vitro digestibility of corn stover silage; however, the interaction between expo- sure time and LAB treatment had a significant impact only on IVCPD. Silage fermentation quality depends on the type of microorganisms applied; their growth is affected by two main factors: the exposure time of the microorganisms to the straw and the fermentation additive. The LA production inhibits the effects of other microorganisms. The growth substrate of these microorganisms is mainly protein, such that $\mathrm{D} \times \mathrm{LAB}$ mainly affects IVCPD.

\section{CONCLUSION}

In this study, we examined the chemical composition and in vitro digestibility of field-exposed corn stover and the fermentation characteristics of silage prepared using microbial additives. Fresh corn stover had levels of certain nutrients that are characteristic of good ensilage materials. Corn stover generally lost nutrients during exposure. Ensilage preserved nutrients well, and our findings indicate that silage should be prepared using fresh stover. The addition of LAB and cellulase improved fermentation and in vitro digestibility of corn stover silage. 


\section{CONFLICT OF INTEREST}

We certify that there is no conflict of interest with any financial organization regarding the material discussed in the manuscript.

\section{ACKNOWLEDGMENTS}

This study was supported in by National Natural Science Foundation of China (NO. 31702178), and in part by National Beef Cattle Industrial Technology System of China (NO. CARS-37), and in part by Jilin Scientific and Technological Development Program of China (NO. 20160520058JH).

\section{REFERENCES}

1. Pang H, Zhang M, Qin G, et al. Identification of lactic acid bacteria isolated from corn stovers. Anim Sci J 2011;82:64253. https://doi.org/10.1111/j.1740-0929.2011.00894.x

2. Wilkinson JM, Phipps RH. The development of plant components and their effects on the composition of fresh and ensiled forage maize: 2 . The effect of genotype, plant density and date of harvest on the composition of maize silage. J Agric Sci 1979;92:485-91. https://doi.org/10.1017/S0021859600063024

3. Muck RE, Emg N, Mcallister TA, Contreras-Govea FE, Santos MC, Kung Jr, L. Silage review: recent advances and future uses of silage additives. J Dairy Sci 2018;101:3980-4000. https:// doi.org/10.3168/jds.2017-13839

4. Li M, Zi XJ, Zhou HL, Hou GY, Cai YM. Effects of sucrose, glucose, molasses and cellulase on fermentation quality and in vitro gas production of king grass silage. Anim Feed Sci Technol 2014;197:206-12. https://doi.org/10.1016/j.anifeedsci. 2014.06.016

5. Filya I. The effect of Lactobacillus buchneri and Lactobacillus plantarum on the fermentation, aerobic stability, and ruminal degradability of low dry matter corn and sorghum silages. J Dairy Sci 2003;86:3575-81. https://doi.org/10.3168/jds.S00220302(03)73963-0

6. Pholsen S, Khota W, Pang H, Higgs D, Cai Y. Characterization and application of lactic acid bacteria for tropical silage preparation. Anim Sci J 2016;87:1202-11. https://doi.org/10.1111/ asj. 12534

7. Sun L, Wang ZJ, Gentu G, Jia Y, Hou M, Cai Y. Changes in microbial population and chemical composition of corn stover during field exposure and effects on silage fermentation and in vitro digestibility. Asian-Australas J Anim Sci 2019;32:81525. https://doi.org/10.5713/ajas.18.0514

8. AOAC. Official methods of analysis. 18th edn. Association of Official Analytical Chemists, Washington, DC, USA: AOAC International; 2005.

9. Van Soest PJ, Robertson JB, Lewis BA. Methods for dietary fiber, neutral detergent fiber, and nonstarch polysaccharides in relation to animal nutrition. J Dairy Sci 1991;74:3583-97. https://doi.org/10.3168/jds.S0022-0302(91)78551-2

10.Deriaz RE. Routine analysis of carbohydrates and lignin in herbage. J Sci Food Agric 1961;12:152-60. https://doi.org/10. 1002/jsfa.2740120210

11. Playne MJ, McDonald P. The buffering constituents of herbage and of silage. J Sci Food Agric 1966;17:264-8.

12.Huang YY, Si R, Chen XB, et al. Feeding of cattle, sheep and goats. Beijing, China China: Agricultural University Press; 2013. pp. 140-54.

13. Owens VN, Albrecht KA, Muck RE. Protein degradation and ensiling characteristics of red clover and alfalfa wilted under varying levels of shade. Can J Plant Sci 1999;79:209-22. https:// doi.org/10.4141/P98-034

14. Robinson D. Compensatory changes in the partitioning of dry matter in relation to nitrogen uptake and optimal variations in growth. Ann Bot 1986;58:841-8. https://doi.org/10.1093/ oxfordjournals.aob.a087266

15. Tilley JMA, Terry RA. A two-stage technique for the in vitro digestion of forage crops. Grass Forage Sci 1963;18:104-11. https://doi.org/10.1111/j.1365-2494.1963.tb00335.x

16. Filya I, Sucu E, Karabulut A. The effect of Lactobacillus buchneri on the fermentation, aerobic stability and ruminal degradability of maize silage. J Appl Microbiol 2006;101:1216-23. https://doi.org/10.1111/j.1365-2672.2006.03038.x

17. McEniry J, King C, O'Kiely P. Silage fermentation characteristics of three common grassland species in response to advancing stage of maturity and additive application. Grass Forage Sci 2014;69:393-404. https://doi.org/10.1111/gfs.12038

18. Pordesimo LO, Hames BR, Sokhansanj S, Edens WC. Variation in corn stover composition and energy content with crop maturity. Biomass Bioenerg 2005;28:366-74. https://doi.org/ 10.1016/j.biombioe.2004.09.003

19. Rambau MD, Fushai F, Baloyi JJ. Productivity, chemical composition and ruminal degradability of irrigated napier grass leaves harvested at three stages of maturity. S Afr J Anim Sci 2016;46:398-408. https://doi.org/10.4314/sajas.v46i4.8

20.Conaghan P, O’Kiely P, O’Mara FP. Possibilities of increasing the residual water-soluble carbohydrate concentration and aerobic stability of low dry-matter perennial ryegrass silage through additive and cultivar use. Grass Forage Sci 2012;67: 177-98. https://doi.org/10.1111/j.1365-2494.2011.00833.x

21. Waroon K, Pholsen S, Higgs D, Cai Y. Fermentation quality and in vitro methane production of sorghum silage prepared with cellulase and lactic acid bacteria. Asian-Australas J Anim Sci 2017;30:1568-74. https://doi.org/10.5713/ajas.16.0502

22. Cao Y, Fang J, Matsuzaki M, Suzuki H. Effects of apple pomace proportion levels on the fermentation quality of total mixed ration silage and its digestibility, preference and ruminal fermentation in beef cows. Anim Sci J 2016;87:217-23. https:// doi.org/10.1111/asj.12410

23.Zhang Q, Yu Z, Wang X. Isolating and evaluating lactic acid 
bacteria strains with or without sucrose for effectiveness of silage fermentation. Grassl Sci 2015;61:167-76. https://doi. org/10.1111/grs.12097

24. Jahanzad E, Sadeghpour A, Hashemi M, et al. Silage fermentation profile, chemical composition and economic evaluation of millet and soya bean grown in monocultures and as intercrops. Grass Forage Sci 2016;71:584-94. https://doi.org/10. 1111/gfs. 12216

25. Heinritz SN, Martens SD, Avila P, Hoedtke S. The effect of inoculant and sucrose addition on the silage quality of tropical forage legumes with varying ensilability. Anim Feed Sci Technol 2012;174:201-10. https://doi.org/10.1016/j.anifeedsci.2012. 03.017

26. Contreras-Govea FE, Muck RE, Armstrong KL, Albrecht KA. Nutritive value of corn silage in mixture with climbing beans.
Anim Feed Sci Technol 2009;150:1-8. https://doi.org/10.1016/ j.anifeedsci.2008.07.001

27. Santos WCCD, Nascimento WGD, Magalhães ALR, et al. Nutritive value, total losses of dry matter and aerobic stability of the silage from three varieties of sugarcane treated with commercial microbial additives. Anim Feed Sci Technol 2015;204: 1-8. https://doi.org/10.1016/j.anifeedsci.2015.03.004

28. Al-Masri MR. In vitro rumen fermentation kinetics and nutritional evaluation of Kchia indica as affected by harvest time and cutting regimen. Anim Feed Sci Technol 2010;157:5563. https://doi.org/10.1016/j.anifeedsci.2010.01.013

29. Méchin V, Argillier O, Rocher F, et al. In search of a maize ideotype for cell wall enzymatic degradability using histological and biochemical lignin characterization. J Agric Food Chem 2005;53:5872-81. https://doi.org/10.1021/jf050722f 